\title{
The Generous Ethic of Deleuze
}

\author{
Finn Janning \\ Independent Philosopher
}

\begin{abstract}
This paper argues that the affirmative philosophy of Gilles Deleuze opens for a generous ethic. Such ethic passes on new or different possibilities of life. The paper briefly outlines the basic ideas in Deleuze thinking that can be understood as generous. Then it suggests how paying attention is a prerequisite for practicing a generous ethics, that is, mainly being aware of what, how and why something happens. Finally, it exemplifies how-referring to Christopher Nolan’s film Inception —-we may practice a generous ethic.
\end{abstract}

Keywords: Deleuze, ethics, affirmative, generous

Western philosophy begins with a metaphysical bifurcation that still forms, organizes, and challenges philosophical thought up to the present day. Heraclites, a pre-Socratic philosopher, emphasized the primacy of a changeable and emergent world, whereas Parmenides, his successor, claimed that the nature of reality was permanent and unchangeable. The clash was between a metaphysic of change or becoming versus a metaphysic of being.

Plato followed in the tradition of Parmenides with such elegance and strength that Whitehead many years later in Process and Reality would suggest that the “... safest general characterization of the European philosophical tradition is that it consists of a series of footnotes to Plato” (Whitehead 1929, 32).

The French philosopher Gilles Deleuze is perhaps a footnote, although he disagrees strongly with Plato's metaphysic of being. Like Whitehead, Deleuze can be described as a "process philosopher," but here I prefer linking him to his affirmative practice that releases life where it is kept imprisoned (Deleuze 1994; Janning 2013, 2014).

In this paper, I will argue that Deleuze's ethics is generous due to its affirmative approach. The affirmative philosopher actively confirms what he or she has seen, when saying "yes." That is accepting that he or she has seen "Life in the living or the Living in the lived," which makes the philosopher "breathless and with bloodshot eyes... they have seen something in life that is too much for anyone, too much for themselves, and has put on them the quit mark of death” (Deleuze and Guattari 1994, 172). They have experienced the process of becoming also a process of dying.

The phrase "generous ethics" refers to the ordinary use of the term generosity where a person "freely gives or shares" something, passes it on. Although, the common use of generosity often implies that it is money that is being shared, here it solely refers to the sharing or passing on of human experiences, that is, forms of life. Being generous, thus, is related to producing or establishing new possibilities for life. It does so by exploring and experimenting with how life also could be. It presents alternatives. For this simple reason it is, like most ethics, risky. Art.

Finn Janning, Ph.D., independent philosopher, Spain; main research fields: Ethics, Deleuze, Mindfulness, and Contemporary 
One common view is that being ethical is measured according to a transcendent set of values or moral categories. The key idea in this paper is different. Following Deleuze's understanding of ethic as something immanent, it becomes difficult, if not impossible, to act generously in a strategic way. In other words, what is passed on or shared doesn't represent anything, nor is it necessarily useful. It's an experiment.

A generous ethics creates or establishes a temporary foundation where future generations are free to invent new forms of life, that is, create new foundations of life. The normative criterion is, therefore, to move beyond our present human experiences, but nevertheless remain faithful to what it means to experience life in the living.

\section{Believe in This World}

Similar to Heraclites and his contemporary colleague, Siddharta Gautama, the Buddha himself, Deleuze claims that everything is changing.

The world is impermanent. Experiencing this can help one overcome the suffering that changes inevitably cause: for instance, growing old, sickness, loss of friends and family, death, etc. Instead of seeing sickness or old age as differences according to an ideal such as healthy and youth, it is seen as a passage that can raise our level of awareness. It's a process of maturing. For instance, despite of your ageing you can still go on living, that is, overcome the problem that age may produce such experience is joyous (e.g., Spinoza).

In alignment, it's the dominant belief in metaphysics of being that makes us suffer. For example, when metaphysics becomes an epistemology, a demand for experiencing what something is as something specific. Or when someone becomes almost blindly certain it matters of truth. This is also related to religious or political fundamentalism. The problem is that a certain state of being functions as a stable ideal or norm that encourages or even forces people to live up to inhabiting such a being. People judge their lives according to such an ideal. This is also what causes stress and anxiety when people strive to be recognized according to the ideals that give prestige and status in today's achievement society (Janning 2014).

Still, what actually is, as Whitehead said, is a process and such a process “... is the becoming of actual entities” (1929, 26). What there actually is, therefore, is constituted by its becoming. For this reason, Nietzsche also spoke about affirming what is different-not just confirming what is known and fits a certain being; but instead an affirmation of difference opens for "the pleasure of knowing oneself different" (Nietzsche quoted after Deleuze 2003, 9).

There is a curious and humble attitude in such an affirmative approach.

How does one come into contact with what is real? Which experience is real?

The short answer is that it requires awareness. We need to pay attention to the virtual that is "Real without being actual, ideal without being abstract” (Deleuze 1994, 208). To affirm is to embody a certain approach, not to represent a system of thoughts. This emphasizes that we are always placed in-between a past which is not yet over and a future that is not yet here. The present moment is stretched out in-between infinite past and future. Deleuze writes, we "always have as much truth as we deserve in accordance with the sense of what we say" (Deleuze 1994, 154). We are, in other words, accountable for what we actualize because it points towards what we are becoming.

An affirmative philosophy is about trusting this particular life that we live in this world. "Belief is no longer addressed to a different or transformed world. Man is in the world as if in a pure optical and sound 
situation. The reaction to which man has been disposed can be replaced only by belief. Only belief in the world can reconnect man to what he sees and hears” (Deleuze 2000, 172).

Establishing such belief is an ethical process.

To live ethically is not to be unworthy of what happens. Ethic is a form of life worthy of accepting what life has to offer. Not worthy in the sense that you should live up to certain ideals or norms, but rather that you are capable of embracing what actually takes place. Carry your experiences with you. It's a sensuous approach full of concentration, attention, and observation. ${ }^{1}$ It matters whether you pay attention or not. Simone Weil describes it beautifully when she says that attention "consists of suspending our thought, leaving it detached, empty and ready to be penetrated by the object," then adding that attention is “... not seeking anything, but ready to receive in its naked truth the object which is to penetrate it” (Weil 2009, 111). Not seeking anything.

Paying attention is connected with the belief that Deleuze asks for. "We need an ethic or a faith," he writes, continuing: "which makes fools laugh; it is not a need to believe in something else, but a need to believe in this world, of which fools are a part. The modern fact is that we no longer believe in this world. We do not even believe in the events which happen to us, love, death, as if they only half concerned us” (2000, 172).

To establish or reestablish a belief, "not in a different world, but the link between man and the world, in love or life, to believe in this as in the impossible, the unthinkable, which none the less cannot but be thought: 'something possible, otherwise I will suffocate'” (Deleuze 2000, 172). The state of the world makes the philosopher "suffocate” or "breathless" with "bloodshot eyes," as I mentioned earlier. To affirm life is also to battle with what hinders it in living.

An affirmative philosophy is non-dual. For example, in Bergsonims he wrote, “... perception puts us once into the matter, is impersonal, and coincide with the perceived object” (Deleuze 2002a, 25). The subject and object melt together. Non-duality means "not two" or "non-separation." The concept stresses that all things are interconnected, not separate, while at the same time, all things retain their singularity. There is not one without another, but the one is not the other. Non-duality refers to an ongoing state of becoming. Just becoming as in being-many, a multiplicity. The process of becoming doesn't end; for example, you can't become woman per se, because each woman already is a multiplicity. Such an example also stresses why becoming can liberate us from rigid gender identities and stereotypes. Every human being is a dynamic process, not a fixed identity. "Philosophy must constitute itself as the theory of what we are doing, not as a theory of what there is" (Deleuze 1991, 133). ${ }^{2}$ For this reason, it is useful to familiarize yourself with how thoughts and feelings emerge, how these constitute you. We are constantly placed on a social scene full of ideas and thoughts that affect us, which again raise the question "what to pass on?" or "what are we becoming?"

There are, of course, things that I can't change, for example, that I was born in Denmark, but I can always change my relationship with life by actualizing other dimensions. For example, I don’t ask: What does it mean to "come from" Denmark? Rather, I ask: What kind of problem does the notion "come from" produce? To "come from" might imply an origin, true or authentic idea of what it means to be Dane. Such a norm, of course, can easily break the flow of life. Is a misfit Dane still a Dane?

The framing of the questions illustrate whether the underlying fundament is one of being or becoming. To experience, therefore, is an engaged and creative action. The challenge is to allow the encounter-whatever affects us - to deliver all its power and strength; that is to say, go to the limits of what it can do. Then we can see how much of it we can carry on. 


\section{Inception}

Now it's time for looking more thoroughly at the film Inception.

Inception is written, produced, and directed by Christopher Nolan. It premiered in 2010, and I will try to illustrate some of the difficulties practicing an affirmative or generous ethic of Deleuze.

How does one come into contact with what is real? Which experience is real?

Inception is a film about a professional thief called Cobb (played by Leonardo DiCaprio), who specializes in corporate espionage. In practice, he infiltrates the unprotected or unconscious mind of another person-for example, innovative business leaders - in order to extract his or her lucrative ideas. It is also a love-story, a story of a father who misses his kids, corporate capitalism, immaterial labor, dreams, and consciousness. And, more importantly, it's a film about life and death where Cobb's relation with the world is dying, until he seriously destroys what hinders him in actualizing what is alive in his life, that is, his relation with is kids.

The film opens with Cobb failing a job. Afterwards, the businessman who Cobb failed to extract any ideas from offers the thief another chance. Salvation or redemption presents itself. The offer consists in performing a task considered to be impossible: inception. Instead of extracting an idea, Cobb will have to implant an idea into the unconscious mind of another. To tighten the plot, Cobb needs the job if he wants to return to the US to see his kids again. He cannot return to the US because he is accused of killing his wife, the mother of his two kids. Soon the viewer realizes that Cobb did not kill her, although he manipulated her into committing suicide. He implanted an idea in her mind that changed her conviction about what is dream and what is reality.

He changed her metaphysic of being into another being.

Whether Cobb is guilty or not, depends, therefore, on what is real or unreal. Can he even be guilty of what he is being accused of? Is he accused due to a "false" metaphysic of being?

Cobb is presented as a person who suffers. He desires what he can't have: a family life together with his wife and kids. Also, he suffers from aversion because he doesn't want what he is having: his past (that led to the death of his wife), nor his present (being accused of murdering his wife, as well as being without his kids) and future (never seeing his children again). Sadness, anger, and fear fill him. Last, Cobb is ignorant, mainly because he doesn't understand how these things are connected. ${ }^{3}$

He doesn't understand how he needs to make himself worthy of what is happening, that is, match the present moment and see what is not yet over (e.g., his relationship with his death wife), and what has not yet been actualized (e.g., being with his kids). He does not understand his karma: how actions bring results.

Karma is a Buddhist concept. It refers to a natural moral law that influences how we experience life. Joseph Goldstein says in Insight Meditation that the "Buddha identified karma as a volitional activity. That is, each volition in the mind is like a seed with tremendous potential. In the same way that the smallest acorn contains the potential of a great oak tree, so too each of our willed actions contains the seed of karmic results. The particular result depends on the qualities of mind associated with each volition. Greed, hatred, and delusion are unwholesome qualities that produce the fruits of suffering; generosity, love, and wisdom are wholesome factors that bear fruits of happiness” $(2003,124)$.

Karma does not imply that one's actions bring about predetermined results. It was not written anywhere that Cobb's actions would cause the death of his wife, but they did. Each action is a seed that will bear some fruit, but what that particular fruit will be depends on many different conditions interacting in a complex myriad of ways. This is why a generous and affirmative philosophy is about taking responsibility of what to 
bring into the future. It's not a philosophy without any critical strength. It learns from experience, but without believing that the past will continue into the present and future without any changes. For example, Cobb incepts an idea in the mind of his wife; he plants a seed. Unfortunately, the inception was not born out of generosity, love, or even wisdom, but a selfish need to control her. He doesn't open her reality by offering new forms of life. On the contrary, he eliminates all but one. This illustrates the main problem when operating with a metaphysic of being. It hinders life to grow and flourish. This action brings about - rather paradoxically-a strong belief in his wife's mind that confuses dreaming with reality, a belief that Cobb cannot control. While she is convinced that she is awake, he believes that only he knows the difference.

Which experience is real?

For Cobb and his wife (that he meets frequently in his dreams), the metaphysical question becomes one of positions. A bitter and devastating fight about who is right and wrong.

Inception addresses the problem of human existence in a world where the traditional order of metaphysics no longer works. The challenge is, how does one experience becoming?

To answer that question we may ask another, “What structures Inception?” I propose, it’s the metaphysical question that organizes: Which experience is real? Apparently (perhaps even obviously), the difference between reality and dream matters; it is a question of life and death in the film. Knowing the difference is a matter of consciousness where one has a direct experience with life, where one is seeing, hearing, touching clearly.

However, can we ever really know? Can we be certain? Seeing the film, it is difficult to draw a clear distinction, as if there was none.

The answer depends on our awareness or consciousness. Consciousness, therefore, has no other object than becoming with what happens, as it folds around itself. What is inside or outside becomes inseparable. Similarly, the unconscious can be viewed as a rhizome with no clear beginning or end. The unconscious is a potential or virtus still not conscious—still not actualized or experienced.

The rhizome is not vertical; rather, it is horizontal (Deleuze and Guattati 2000). It connects any point with any other points. For this reason, the rhizome cannot be reduced to either the one or the other; there is no origin. Both Cobb and the wife are right and wrong. Similarly, one can only implement an idea, because there is no clear origin. No one really owns or possesses his or her ideas; they are all implanted by the life that rushes through one's body and mind. The rhizome is made up of lines intersecting with other lines that change any previous structure. That's why maps always are temporary, as if written on the surface of the ocean. The changes do not happen according to any specific future structure or master plan (which was exactly what Cobb tried to when he installed an idea in his wife's mind). Instead, the rhizome draws a new map or opens to a new territory by constantly relating or connecting with what is in the midst of becoming. The capacity to relate is crucial. A rhizome is, therefore, like what we traditionally refer to as an unconscious mind that potentially is open and changeable. No one really knows what the unconscious is until one becomes conscious, that is, one actualizes what was unclear.

All human beings are the sum of his or her actions. All actions are part of a larger interrelated or interdependent relationship of causes and effects. What matters is how one relates with what happens: dreams, hallucination, delusions, and ideas.

Is one's relation unwholesome or wholesome? Motivated by generosity or greed? Asking these questions, I may want to ask another, more fundamental: Why does your motive matter? 
I propose that the answer is related to whether the act is generous or not. Or as Deleuze says, referring to the writer, when he writes, "the writer writes for, not to...” Is it our collective life that is passed on, if not, I am just acting out of pure vanity or egoism (as Cobb).

Cobb, when he changed his wives believe, didn't change it for, but to achieve something specific. He acted as if he was managing by objective. An affirmative or generous approach produces alternatives, they "write" for those who cannot express themselves, never to control.

\section{Perspectives}

Inception shows that an idea is constantly created due to a metaphysic of becoming, while an idea is being manipulated and controlled with the sphere of metaphysic of being.

An idea is not created or constructed in the sense of social constructivism; rather the creation is a relationship with what takes place or happens. "You will know nothing through concepts unless you have first created them - that is, constructed them in an intuition specific to them: a field, a plane, and a ground that must not be confused with them but that shelters their seeds and the personae that cultivate them. Constructivism requires every creation to be a construction on a plane that gives it an autonomous existence. To create concepts is, at the very least, to make something," writes Deleuze with Félix Guattari in What Is Philosophy? $(1994,5)^{4}$

The unconscious takes up its consciousness in the middle as a movement from a mere slumbering awareness to a focused attention. However, one needs to create a concept to facilitate this maneuver, but before one can construct a concept, one needs to problematize, to engage oneself with the present moment. According to Deleuze and Guattari, then "... concepts are only created as a function of problems which are thought to be badly understood or badly posed.”

An example of a badly posed problem is unfolded in Inception. The implementation of an idea is only seen as impossible, because we understand the real as something solid and given (i.e., a metaphysic of being). Cobb's assignment is difficult within the frame of what is real versus possible. However, this dualism is the problem, because the possible will often consist of more realities than what is realistic. Instead, Deleuze and Guattari proposed operating with the virtual or potential and the actual. The virtual is real, but not yet actualized. This possible world where Cobb can implement an idea exists, so far; however, it exists only in its expression. It is not yet actualized. It emphasizes that the world is not given as something static and stable; rather we are dealing with a metaphysic of becoming. Cobb cultivates the problem of implementation when he makes it a matter of how open and receptive, not rejecting or judging, the other person is.

In the film, this is symbolized by the whiteness of the snow; however, whiteness is not only something sacred or our blind spot. It is pure potential, the joker in a play of cards.

In Difference and Repetition, Deleuze wrote, "The virtual possesses the reality of a task to be performed or a problem to be solved: It is the problem which orientates, conditions and engenders solutions, but these do not resemble the conditions of the problem" (Deleuze 1994, 212).

In the film, the solution resembles the idea that the son (i.e., the victim of the implantation of the idea) wants to feel loved by his father; he wants some sort of resolution. However, the problem that Coob and his collegians produce is that the son still has not accepted what is real but not yet actualized: That he is not his father. Or to put it more precisely: No one owns his or her life. The son does not need to live up to any pre-given identity or role. Thus, Cobb doesn't have to implant an idea; rather he has to liberate the son from his 
illusion, then the rest will take care of itself. So, here Cobb is not controlling, but liberating, freeing the son from what keeps him imprisoned.

The idea is that there is no idea, there is no origin, but an ongoing clarification saying: This is real, this is real, and this is real. Each time the virtual or the potential is being actualized. Freedom lies in the power to decide what seed to plant; what to nurture and how. That is, to constitute the problem that the seed, one day, will overcome it.

The problem in Inception is not that the father died (or that Cobb's wife died), but that taking a decision is an activity of the present moment; it is a function of time. What is at stake right here and now? How does one live up to what happens?

The point is to avoid engaging in life through a veil of assumptions and predefined beliefs, but interact openly and with curiosity. There is no outside or ideal world that one can refer to as a benchmark. Instead, philosophy is a sensible act where one becomes familiar with what happens at the same time as one transforms with what is happening. To problematize is, therefore, to raise questions, unfold, experiment, and explore. Doing so forces people to think. It never raises questions for people to see a specific point of view. Philosophy is not a quiz show where the philosopher knows the answers beforehand. On the contrary, it's an unsolvable problem that provokes philosophical thinking. Something takes place that cannot be rubricated or classified. Thus, we need to encounter what happens unarmed as well as with a high level of awareness. Folding, unfolding, and refolding. All this folding is a sensible and intuitive practice.

Recently, the director Christopher Nolan gave a commencement speech at Princeton. Nolan said, "In the great tradition of these speeches, generally someone says something along the lines of 'Chase your dreams,' but I don't want to tell you that because I don't believe that. I want you to chase your reality.”,

Reality, he claimed, has turned reality into the poor cousin of our dreams. We live in a society that encourages us to dream, not only due to advertising, but also due to managerial and educational tools encouraging people to live in pursuit of dreamy objectives. Dreaming is about certain self-images full of prestige, status, power, and money. Nolan goes on to say, "I want to make the case to you that our dreams, our virtual realities, these abstractions that we enjoy and surround ourselves with-they are subsets of reality."

Another way of saying this could be that our mental default setting is not to really see reality as it emerges, but as how we would like it to be. We see what we expect to see, which, unfortunately, makes us blind to each present moment. Capitalism, for example, is quite good at blinding people, making them suffer in order to live up to financial ideal and norms - a metaphysic of being - that only break the flow of life.

Reality matters because our life and life in general matters. If the world is changing, then nothing exists in itself. If nothing exists in itself, everything depends on our relationship with life, that is, our approach to life. Is it open and receptive or is it already guided by moral categories, stereotypes, norms, and transcendent ideals? So, which reality is real depends on how we relate to the world.

To be aware of what is happening, this is not turning the present moment into a Holy Grail or object, as in new-age philosophy (Purser 2015). Rather, it's a way of being with the world that changes moment to moment. What matters is the relationship between each instant. That is what we bring into life here and now.

How does one relate to each moment, each instant, when one is conscious that what arises is also in the midst of passing away? Every moment we die, the next we are born again. It is the acceptance of our vulnerability that is the driven motor of a generous ethic; we protect and pass on life for future generations. A generous ethic is not an ego-trip, nor is it "just" a passive sympathy feeling for the others, which is not that 
different from feeling sympathy for the devil. One needs to act. Socially, that is, activate our collective capacity to be affected and produce new forms of life. It's a process of becoming someone else.

\section{Conclusion}

In Inception Cobb moves on in his life when he opens up to the future's potentiality and let's go of the past's desires. The film ends with Cobb being home with his kids. One inevitably asks: Is he really there, or is it just another dream? The answer matters, as Nolan also stressed in his speech, because only in reality does one moment arise and pass away, whereas in dreams nothing really ends. And if it does not end, then it does not really matter.

An affirmative philosophy is generous because it makes a clear distinction between what we are ceasing to be and what we are becoming. It passes on what it can never own: life. The film ends with the father arriving at his home, seeing his kids playing, while the audience doesn't really know. Is this it? Or better: The film ends with an act of love: It gives us what we can never have: certainty.

\section{Notes}

1. In Gilles Deleuze from A to Z, he refers to himself as going to the cinema or art exhibitions as being "on the lookout," like an animal taking a drink at a waterhole in the savanna: aware, alert, and receptive.

2. In this work, Deleuze also mentions, "relations are always external to their terms” (p. x, 66, 99 and 101). Everything begins in the middle; the outside forms us.

3. Connected doesn't mean that things are predictable. For example, the car was created as a personal mean of transportation, not a personal space where one can meditate, converse, or listen to music. What makes sense changes due to context as well as general changes in society, for example, today it is difficult to find zones of non-doing.

4. The quote is a reference to what the two authors call the "Nietzsche verdict" that says "Philosopher must no longer accept concepts as a gift, nor merely purify and polish them, but first make and create them, present them and make them convincing" (ibid., 5).

5. “Christopher Nolan Talks 'Inception’ Ending, Batman and ‘Chasing Reality’ in Princeton Grad Speech” taking from: http://www.hollywoodreporter.com/news/christopher-nolan-princeton-graduation-speech-799121 (accessed May 12, 2016).

\section{Works Cited}

Deleuze, Gilles. Empiricism and Subjectivity. An Essay on Hume's Theory of Human Nature. Translated and with introduction by Constantin Boundas. New York: Columbia University Press, 1991.

---. Difference and Repetition. Trans. Paul Patton. New York: Columbia University Press, 1994.

---. Cinema 2. The Time-Image. Trans. Hugh Tomlinson and Robert Galeta. London: The Athlone Press, 2000.

---. Nietzsche and Philosophy. Trans. Hugh Tomlinson. Continuum. 2002.

---. Bergsonism. Trans. Hugh Tomlinson and Barbara Habberjam. New York: Zone Books, 2002a.

Deleuze, Gilles \& Guattari. Félix. What Is Philosophy? Trans. Hugh Tomlinson and Graham Burchell. New York: Columbia University Press, 1994.

---. A Thousand Plateaus. Capitalism and Schizophrenia. Trans. Brian Massumi. Minneapolis: University of Minnesota Press, 2000.

Goldstein, Joseph. Insight Meditation. The Practice of Freedom. Shambhala Classics. 2003.

Janning, Finn. “Happy Death of Gilles Deleuze.” Tamara Journal of Critical Organisation Inquiry 11.1 (2013): 29.

---. Den gavmilde digter. Et essay om Jørgen Leth (The Generous Poet. An Essay about Jørgen Leth). Mellemgaard. 2014.

---. The Happiness of Burnout. The Case of Jeppe Hein. London: Koenig Books. 2015.

Purser, Ronald. “The Myth of the Present Moment.” Mindfulness 6 (2015): 680-6.

Weil, Simone. Waiting for God. Trans. E. Graufurd. London: Harper Perennial, 2009.

Whitehead, Alfred North. Process and Reality. New York: Macmillan, 1929. 